\title{
エポキシ樹脂の直流破壊電圧に及ぼす 充てん剂の効果
}

\begin{tabular}{|l|}
\hline 論 文 \\
\hline $56-\mathbf{A 1 5}$ \\
\hline
\end{tabular}

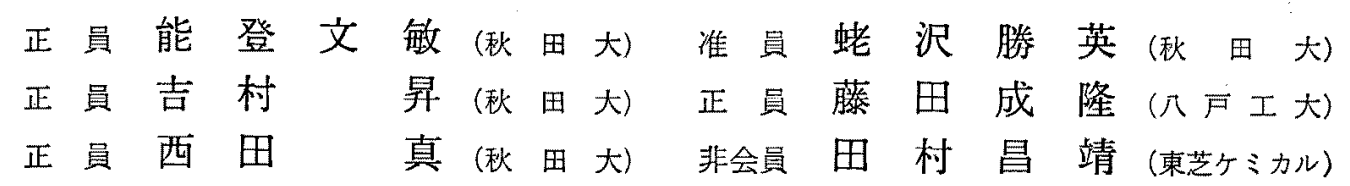

\section{1. まえがき}

近年の高分子材料の進歩汇目覚ましいむのがあ り，種々の優れた電気的あるいは機械的特性を有する 材料が改質あるいは改良を加えられて登場してきた。 そのなかにあって，エポキシ樹脂についても種々の目 的に応じて改良が加えられ，現在は電気絶縁材料とし ての用途が注目をあびている。

一般に，エポキシ福脂を電気絶縁材料しして用いる 場合，単体での利用よりも種々の特性要求に合わせて 各種充てん剂を湜合して利用するてとが多い。充てん 剂としては無機系の粉末粒子が広く用いられている。 エポキシ樹脂に充てん猟を湜入することによる材料の 各種の特性については検討が加えられている(1)。しか し，電気絶縁材料として最む基本的であり，加つ重要 な電気的特性の一つである絶縁破壤強度ならび沉絶縁 破壊機構についての具体的な検討は少ない(2)。

以上の背景により，本論文では

（1）エポキシ樹脂単体の絶縁破液機構

（2）絶縁破壊強度に及ぼす充てん剂（無機系粉末 粒子) の影響

（3）絶縁破壊機構に及ぼす充てん剂の影響 の3点について，室温 $\left(20^{\circ} \mathrm{C}\right)$ より $220^{\circ} \mathrm{C}$ までの広い 温度笧囲で検討した。以下に得られた実験扔よび検討

Effect of Filler upon DC Breakdown Voltage of Epoxy Resin. By Fumitoshi Noto, Member, Noboru Yoshimura, Member, Makoto Nishida, Member, Shoei Ebisawa, Associate (Mining College, Akita University), Shigetaka Fujiza, Member (Hachinohe Institute of Technology) \& Masayasu Tamura, Non-member (Toshiba Chemical Co.). 能登文敏：正員，秋田大学鉱山学部䈈気工学科

吉村 界：正員，秋由大学鉣山学部電気工学科

西田 真: 正員, 秋田大学䅝山学部電気工学科

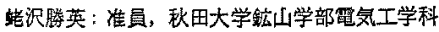

藤田成隆: 正員, 八戸工業大学電気工学科

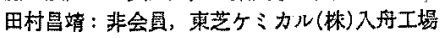

結果について報告する。

\section{2. 試料および実験方法}

〈2・1〉試 料本論文で用いた試料の種類は。 ビスフェノールA形注型エポキシ樹脂（密度：1.20, 比誘電率 $\left.\varepsilon_{1 s}: 3.0\right)$ である。硬化条件は $\left(115^{\circ} \mathrm{C}\right.$ で 15 時間 $)+\left(130^{\circ} \mathrm{C}\right.$ で 10 時間 $)$ である。第 1 表䎲充てん 剂として用いた無水了ルミナの諸特性を示す。

実験に用いた試料は；充てん成の部数て(樹脂) +(硬 化剂) 100 部に対吉万量了別では $0 ， 5 ， 40,100$, $200 ， 250$ および 300 部の 7 種類である。 7 理類の試 料の部数を体積比 $v_{s}(\%)$ 亿换算した值を第 2 表に示 す。同表中の粒子密度 $n$ は，充てん粒子の平均半径を

\section{第 1 表 無水アルミナの諸特性}

Table 1. Various properties of alumina particle.

\begin{tabular}{|c|c|c|}
\hline 盉 & 類 & 無水アルミナ \\
\hline 比 & 重 & 3.95 \\
\hline 比誘露 & 率 $\varepsilon_{z s}$ & 7.0 \\
\hline 形 & 状 & 球 形 \\
\hline 平均皆 & 径 & $\simeq 5 \mu \mathrm{m}$ \\
\hline 精度分才 & & $D=1 \sim 20 \mu \mathrm{m} \quad$ 辰大 $50 \mu \mathrm{m}$ \\
\hline
\end{tabular}

第 2 表 実験に用いた各部数の試料の体積比， 粒子密度之平均粓子間隔

Table 2. Ratio of volume of filler, filler density and average distance of filler.

\begin{tabular}{|c|c|c|c|c|c|c|c|}
\hline $\begin{array}{ll} & \text { 部数定数 } \\
\end{array}$ & 0 & 5 & 40 & 100 & 200 & 250 & 300 \\
\hline 体櫝比 v $\quad(\%)$ & 0 & 1.5 & 10.8 & 23.3 & 37.8 & 43.2 & 47.7 \\
\hline $\begin{array}{r}\text { 柆子密席 }(n) \times 10^{3} \\
\left.\text { (個/ } 10^{6} \mathrm{~km}^{3}\right)\end{array}$ & 0 & 3.57 & 25.5 & 54.6 & 88.8 & 101.0 & $111 . ?$ \\
\hline 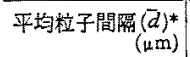 & & 16.2 & 8.4 & 6.5 & 5.6 & 5.3 & 5.2 \\
\hline
\end{tabular}

*: 粒子の中心間距離 

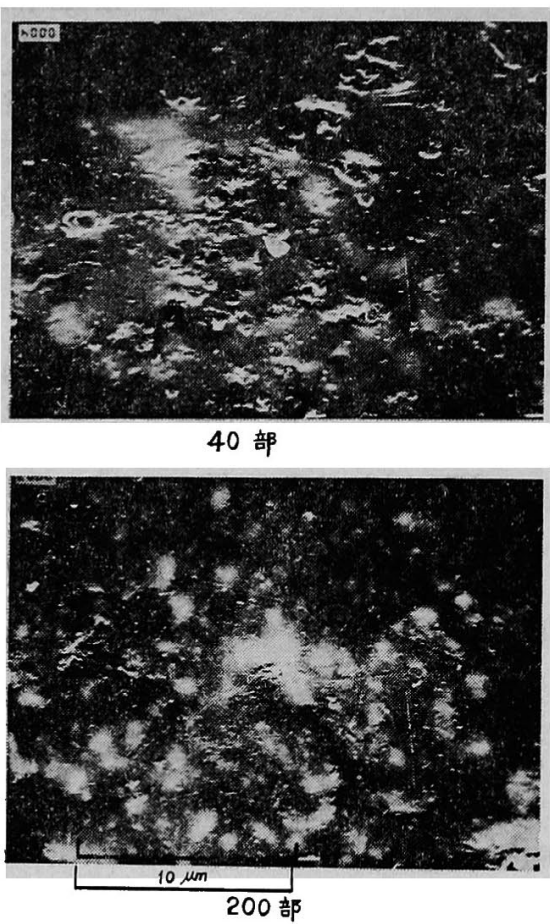

第 1 図 試料表面の電子顕微鏡写真

Fig. 1. Photographs of sample surface by scanning electron microscope.

2. $5 \mu \mathrm{m}$ とし，乙れが試料全体に平等に分布している と仮定した場合の $100 \times 100 \times 100 \mu \mathrm{m}^{3}$ に含まれる平均 粒子数である。また平均粒子間隔 $\bar{d}$ (粒子の中心間距 離）は, 電極間に平均半径 $2.5 \mu \mathrm{m}$ の料子が並んだ場 合の粒子間の距離を意味する。

第 1 図に 40 部および 200 部充てんエポキシ樹脂表 面の 5,000 倍に拡大した電子顕微鏡写真を示す。同図 で白く見える部分が無水アルミナの粒子である。40 部に比較して 200 部充てん試料のほうの白色部分が濃 くなっているととがうかがわれる。

〈2.2〉実験方法負極性直流電圧を $1 \mathrm{kV} / \mathrm{s} の$ 昇圧速度で絶縁破壊が生じるまで昇圧した。なお，一 部の実験に $0.5 \mathrm{kV} / \mathrm{s}, 0.1 \mathrm{kV} / \mathrm{s}$ の昇王速度を採用し た。昇圧速度の調整は, 記録計の出力を見ながらスラ イダックにより手動操作で行なった。室温 $\left(20^{\circ} \mathrm{C}\right)$ での 実験は，10-2 Torr 下で 1 時間脱気処理を行なった高 圧トランス油を， $60 \sim 220^{\circ} \mathrm{C}$ の温度範囲における実験 は,トランス油と同一の条件で脱気処理したシリコー ン油 $(50 \mathrm{cs})$ を周囲媒質として用いた。

絶縁破壊強度 $E_{B D}$ は $\left(V_{B D} / d\right)$ より求めた。ここ で, $V_{B D}$ は直流破壊電圧, $d$ は試料厚さ(電極間距離) である。なお，一つの条件での実験試料個数は 5〜12
個であり，その相加平均値をデータとして採用した。

\section{3. 実験用試料形状決定のための予備的検討}

予備実験に用いた試料は，250 部充てんエポキシ樹 脂である。用いた試料形状は 5 種類であり，それを第 2 図に示す。(a)〜 ( c ) 図は厚さ $2 \mathrm{~mm}$ の注型板材加 ら (d), (e)図は厚さ $5 \mathrm{~mm}$ の注型板材から, それぞ れ第 3 図に示す過程を経て作成した。試料は歯科医用 研摩器を用いて \#100 のサンドペーパーと同一程度に 研摩して所定の厚さとした。研摩の際に生じた切粉を 洗い落とすため，超音波洗浄を 1 時間行なった後，恒 温そうを用いて $60^{\circ} \mathrm{C}, 2$ 時間の乾燥処理を行なった。 電極は半球一平板あるいは半球一半球のいずれかとし, 両面に導電性銀ペイントを塗布した。電極間の距離は $150 \mu \mathrm{m}$ である。実験配固は，正確さを期すためと， 絶縁破壊実験を重ねていくに従って伴う周囲媒質の污 れが $E_{B D}$ によ゙のように影響するかを考虑するため に，ラテン方格法を採用した ${ }^{(3)}$ 。トランス油は第 2 図 ( a )〜 (e) まで 5 種類の試料を一とおり実験するごと に新しいものと交換した。電王印加は試料を油に浸せ きしてから 5 分後に行なった。

第 3 表に実験結果の集計を示す。同表から各々の試 料形状の絶縁破壊強度 $E_{B D}$ をプロットしたのが第 4 図である。なお，実験においてはすべての試料形状に つき絶縁破壊は電極直下の最薄部で起こり，例外は認 められなかった。

実験結果を要約すると次のようになる。

（1）試料形状(c), (d), (e)間に $E_{B D}$ の有意差 が認められない。これらの試料の加工度は一定（片面
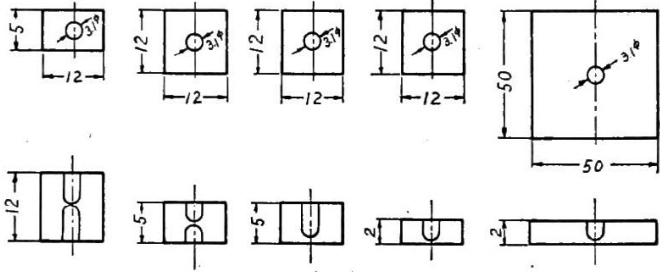

(a)

(b)

(c)

(d)

(e)

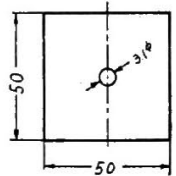

第 2 図予備実験に用いた試料の形状

Fig. 2. Shapes of sample used.

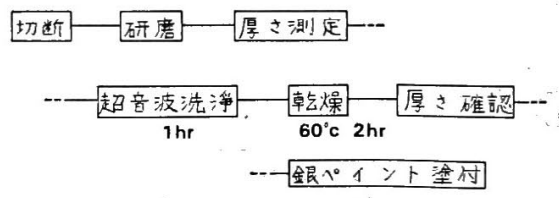

第 3 図 試料の作成過程

Fig. 3. Preparation process of sample. 
第 3 表 実験計画法に上る実験結果の集計

Table 3. Table of experimental results due to experimental planning method.

\begin{tabular}{|c|c|c|c|c|c|c|c|}
\hline 綵返し_便 番 & $O_{t}$ & $\mathrm{O}_{2}$ & $O_{s}$ & 0. & $O_{s}$ & $\left(R_{t o t a t}\right)_{i}$ & $R_{t}$ 平坮 \\
\hline$R_{1}$ & (a) 12.0 & (b) 12.0 & (c) 25.0 & (d) 26.0 & (e) 17.0 & 106.0 & 21.2 \\
\hline$R_{2}$ & (e) 32.0 & (a) 21.0 & (b) 5.0 & (c) 24.0 & (d) 24.0 & 106.0 & 21.2 \\
\hline$R_{3}$ & (d) 26.0 & (e) 24.0 & (a) 20.0 & (b) 16.0 & (c) 22.5 & 108.5 & 21.7 \\
\hline$R$ & (c) 27.8 & (d) 23.0 & (e) 26.4 & (a) 15.5 & (b) 7.0 & 99.7 & 20.0 \\
\hline$R_{5}$ & (b) 9.5 & (c) 25.0 & (d) 35.8 & (e) 27.5 & (a) 18.5 & 116.3 & 23.3 \\
\hline$\left(O_{t o t a}\right)_{i}$ & 121.3 & 105.0 & 112.2 & 109.0 & 89.0 & 536.5 & \\
\hline$O_{t}$ 平均 & 24.2 & 21.0 & 22.4 & 21.8 & 17.7 & & 21.5 \\
\hline 形状別 Tótal & (a) 101.0 & (b) 49.5 & (c) 124.3 & (d) 134.8 & (e) 126.5 & 536.5 & \\
\hline 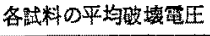 & (a) 20.2 & (b) 9.5 & (c) 24.8 & (d) 27.0 & (e) 25.6 & & 21.5 \\
\hline
\end{tabular}

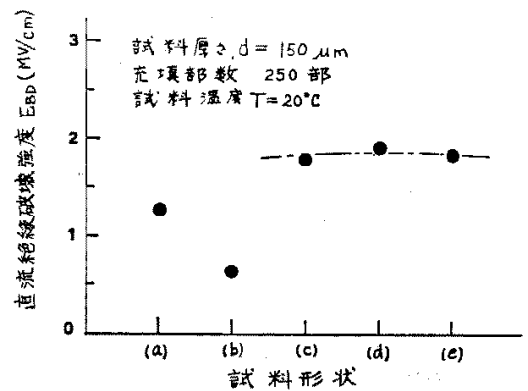

第 4 絶緣破㙲強度にお打試料形状の効果

Fig. 4. Effect of shape of sample on DC breakdown strength.

だけから研摩したという意味)であるてとから，実験 範囲で沿面距離の大小は $E_{B D}$ に影響を及ほささない。

（2）電極面を片面のみから研摩した(c)，(d)， (e)の $E_{B D}$ 亿比較し, 両面加ら研摩した (a), (b) D $E_{B D}$ 加低い。

試料の研摩加工によって $E_{B D}$ が影響を受ける要因 として, 以下が挙げられる。

(i) 表面の粗さ

（ii）加工熱汇よる材料の変質

（㧫）加工時に生ずると思われるびび割れ（ミクロ クラック)

而面加研摩した（a )，(b)の $E_{B D}$ が片面のみから 研摩した(c)〜（e)の $E_{B D}$ に比较して小さくなるの

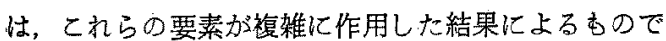
あろう。なお，（i 項の表面粗さの要因については， 表面の仕上げ方法がパフ研摩仕上げ，機械仕上げ，古 るいは \#100のサンドペーパー仕上げ程度の差では， $E_{B D}$ 間にほとんど差が現われないという報告 ${ }^{(4)}$ があ り, 表面粗さの影響は比較的小さいるのと考えられる。 以上の予備的検討結果より，以下本論文では第 2 図 (e)の試料形状を試料として採用した。電極間距離は 主として $150 \mu \mathrm{m}$ であるか， $E_{B D}$ の厚さ依存性の実験 の之きは $50 \mu \mathrm{m}, 100 \mu \mathrm{m}$ も採用した。

\section{4. 絶緑破壊に関する実験結果}

〈4-1〉 絶縁破罗強度の温度依存性第 5 困任充 てん部数をパラメータにした絶縁破壤強度 $E_{B D}$ の温 度侤存性を示す。なお， 0 部の室温 $\left(20^{\circ} \mathrm{C}\right)$ 亿おける結 果のみは，試料厚さ $d=100 \mu \mathrm{m}$ にて行なったもので ある。電源の関係で $d=150 \mu \mathrm{m}$ ては破壊しない。乙 の条件 $\left(0\right.$ 部, $\left.20^{\circ} \mathrm{C}\right)$ では第 7 図仁示すように厚さ依 存性が認められないため， $d=100 \mu \mathrm{m}$ 上 $d=150 \mu \mathrm{m}$ は注等しい $E_{B D}$ を有するすの上考元た。

$E_{B D}$ の温度依存性は, 各部数とす傾向擞似してい る。すなわち，室温 $\left(20^{\circ} \mathrm{C}\right)$ 加 $100^{\circ} \mathrm{C}$ 付近にかけて

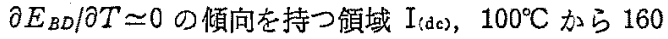
${ }^{\circ} \mathrm{C}$ に加けて急激江 $E_{B D}$ 加低下し $\partial E_{B D} / \partial T \ll 0$ の傾向

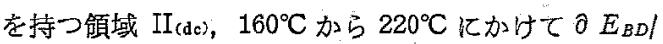
$\partial T<0$ となる領域 III (dc) 亿分けるととができる。領域

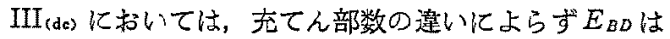
ほぼ一定となる。 $E_{B D}$ に及ぼす充てん部数の影響は， 領域 IIII(dc) を除いた他の領域に求いて，部数が多く なるほど $E_{B D}$ 怯全体的任下する。

\section{〈4·2〉 絶緑破壊強度に及ぼす充てん量の効果}

第6図に試料温度をパラメータにした場合の $E_{B D}$

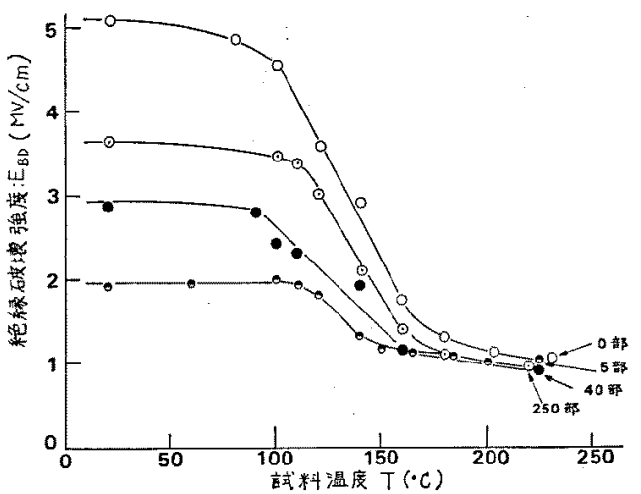

第 5 図絶縁破壊強度の温度依存性 Fig. 5. Temperature dependence of DC breakdown strength. 


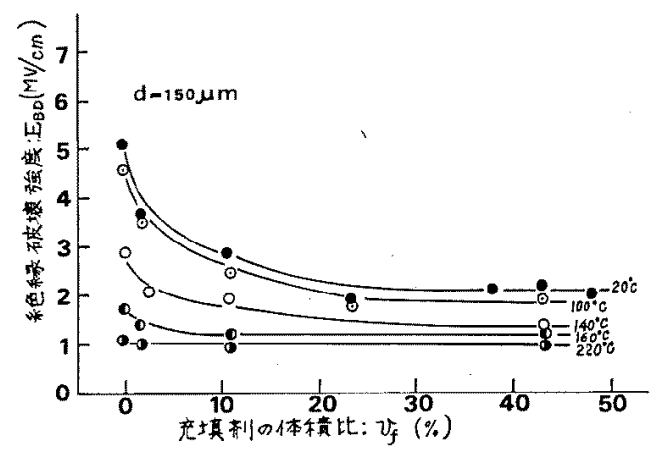

第 6 図 絶䋎破壊強度に求ける 充てん剂体皘比の効果

Fig. 6. Effect of volume of filler upon DC breakdown strength.

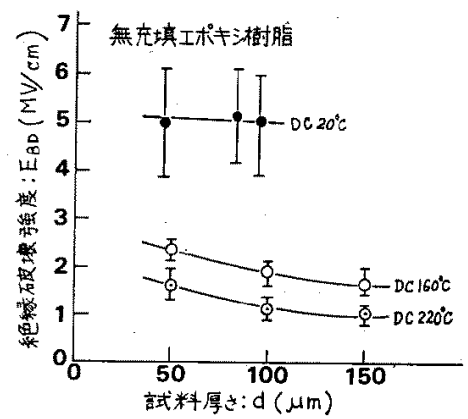

第 7 困 無充てんエポキシ樹脂の絶縁破塆 強度の厚吉依存性

Fig. 7. Thickness dependence of epoxy resin without filler upon DC breakdown strength.

と充てん風の体積比 $v_{f}$ の関係を示す。実験結果を要 約すると次のようになる。

(1) 試料温度が室温 $\left(20^{\circ} \mathrm{C}\right)$ から $100^{\circ} \mathrm{C}$ までの温度

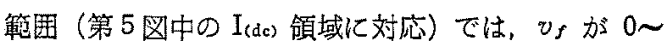
$23.3 \%$ (充て九部数 100 部) にかけて $\partial E_{B D} / \partial v_{\rho}<0$ の 傾向を持つ。一方， $v_{f}$ が $23.3 \%$ (100 部) $\sim 47.7 \%$ (300 部) にかけては，ほほ $\partial E_{B D} / \partial v_{\gamma} \simeq 0$ となる。

(2) 試料温度が $100^{\circ} \mathrm{C}$ から $160^{\circ} \mathrm{C}$ までの温度範 囲（第 5 因中 $I_{(d e)}$ 領域に対応) では，(1) 項の室温

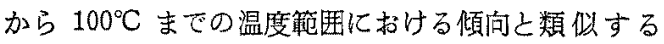
か，試料温度の上显に伴い $E_{B D}$ の值は低下する。

(3) 試料湿度が $160^{\circ} \mathrm{C}$ から $220^{\circ} \mathrm{C}$ までの温度範囲 (第 5 図中 III (ds) 領域仗対応) では，実験範囲内の充て ん斉の体䅡比 $v_{f}$ に挍いて， $\partial E_{B D} / \partial v_{f} \simeq 0$ の傾向を 持つ。

〈4·3〉絶縁破壊強度における厚さ依存性 第 7 困に無充てんエポキシ樹脂の試料温度をパラメー夕に した $E_{B D}$ の厚さ依存性を示す。室温 $\left(20^{\circ} \mathrm{C}\right)$ に扣いて

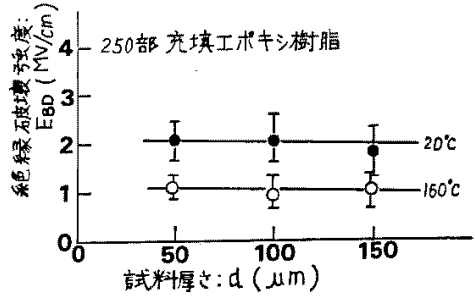

第 8 図 250 部充てんエポキシ樹脂の 絶縁破壊強度の厚さ依存性

Fig. 8. Thickness dependence of epoxy resin with 250 parts filler upon DC breakdown strength.

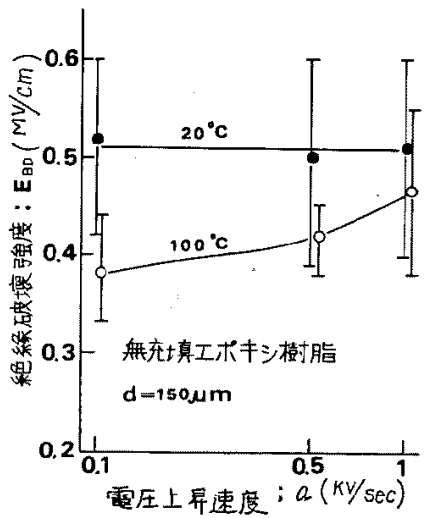

第 9 図 絶縁破壊強度の電圧上界速度依存性

Fig. 9. Dependence of rate of DC voltage rise on breakdown strength.

は $\partial E_{B D} / \partial d \simeq 0$ であるが, $160^{\circ} \mathrm{C}$ および $220^{\circ} \mathrm{C}$ では $\partial E_{B D} / \partial d<0$ の傾向を持つ。第 8 図は 250 部充てん工 ポキシ樹脂の試料温度をパラメータにした $E_{B D}$ の厚

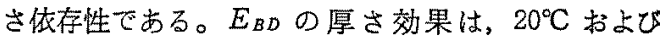
$160^{\circ} \mathrm{C}$ とも $\partial E_{B D} / \partial d \simeq 0$ となる。

\section{$\langle 4.4\rangle$ 絶縁破壊強度の印加電圧上䍙速度依存性}

無充てんエポキシ樹脂の絶縁破壊強度の日加電E上 昇速度依存性を室温 $\left(20^{\circ} \mathrm{C}\right)$ と $100^{\circ} \mathrm{C}$ につて実験した 絽果を第 9 図に示す。 $E_{B D}$ は室温では印加電王上异速 度にほとんど依存しないが，100ㄷ では日加電圧上昇 速度の增加と共に上昇する傾向を持つ。

〈4.5〉 実験データのばらつきについて すべて の充てん部数に共通して，第 5 図中 II (de)，III(de)の 高温領域での絶縁皮罗强度 $E_{B D}$ の標準偏美 $\sigma$ は, $\mathrm{I}$ (dc) の室温領域の $\sigma$ に比べて小さい。また部数別で の $E_{B D}$ のばらつきの一例として室温 $\left(20^{\circ} \mathrm{C}\right)$ における $\sigma$ の結果を第 10 注に示す。また， $\sigma$ の大きさと第 6 図に示した $E_{B D}$ の大きさの比すなわち，変動係数 $\left\{\left(\sigma / E_{B D}\right) \times 100(\%)\right\}$ Kついむ同図中に示す。変動係 数を用いると，各充てん量におけるばらつきの大きさ 


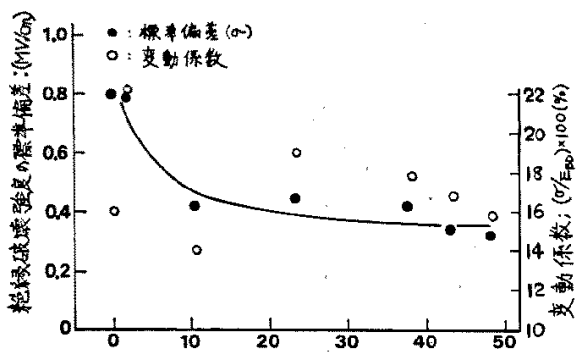

充填剂の体棈比; Vf $(\%)$

第 10 因絶縁破壊強度 $\left(E_{B D}\right)$ の標準偏差 $(\sigma)$ と充てん剂の体積比 $\left(v_{f}\right)$ の関係

Fig. 10. Relation between standard deviation of $E_{B D}$ and $v_{\rho}$.

を此较することができる。第 10 図中では， $v_{f}=1.5 \%$ のとき捽動係数が $22 \%$ と最む高く，他の $v_{f}$ では 14〜19\%となっている。全実験を通じ変動係数の 最大值は $33 \%\left(d=100 \mu \mathrm{m}, T=20^{\circ} \mathrm{C}\right.$, 充てん部数= 5 部， $\sigma=1.21 \mathrm{MV} / \mathrm{cm})$ であり，最小值は $7 \%(d=$ $150 \mu \mathrm{m}, T=220^{\circ} \mathrm{C}$, 充てん部数 $=250$ 部, $\sigma=0.07$ $\mathrm{MV} / \mathrm{cm}$ ) である。

\section{5. 実験結果の検討}

〈5・1〉無充てんエポキシ樹脂の絶縁破壊機構

(1) I (de) 領域 $\left(20 \sim 100^{\circ} \mathrm{C}\right)$ 亿おりる絶縁破㙹機構 この領域での郶縁破壊強度 $E_{B D}$ 亿関する諸特性を 整理すると，（i） $\partial E_{B D} / \partial d \simeq 0$, (ii) $\partial E_{B D} / \partial T \simeq 0$, (iii) $\partial E_{B D} / \partial a \simeq 0[a:$ 印加電升上昇率 $(\mathrm{kV} / \mathrm{s})]$ とな る。すなわち，乙の領域に和ける絶縁破壊機構として は，定性的には電子的過程を考えることができる。電 子的過程のなかで考えられるすのとしては，真性破壊 および電子なだれ破壊がある(5)。真性破壊では, 第 11 区に示すように $7 \times 100 \mu \mathrm{s}$ 衝撃電圧波形を印加した 際儿現われる $E_{B D}$ の厚さ効果 $\left(\partial E_{B D} / \partial d<0\right)$ を説明 することが難しい。なお，衛揧電圧印加による絶緑破 壇強度 $E_{B D}$ は，予想破壞電圧の $10 \%$ 程度の過電纴 を畉加する方法により求めたすのである(6)。

一方，電子なだれ破壇については， $E_{B D}$ の厚さ効果 がほとんど認められないととから，との過程について す断定し難い。しかし，乙の領域にお污る直流電圧と

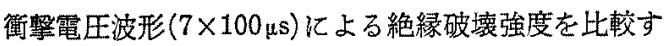
ると(第 12 図)，( $\left(E_{B D}\right)_{\mathrm{dc}}>\left(E_{E D}\right)_{\mathrm{Imp}}$ であることより， 空間電荷効果が㗢いて絶緑破壊機構に何らかの寄与を している可能性む推測される。

(2) II(dc) 扔よび $\operatorname{III}_{(\mathrm{dc})}$ 領域 $\left(100 \sim 220^{\circ} \mathrm{C}\right)$ 亿捛 ける絶縁破壊機構との領域での $E_{B D}$ の諸特性 を整理すると，（i） $\partial E_{B D} / \partial d<0 ，(i i) ~ \partial E_{B D} / \partial T \ll 0$

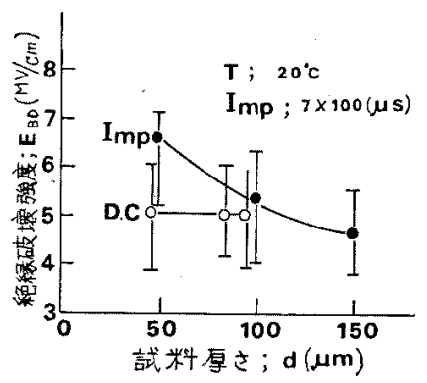

第 11 図 直流扔よび衝撃電圧による 絶縁破壊強度の厚さ依存性

Fig. 11. Thickness dependence of epoxy resin without filler on DC breakdown strength.

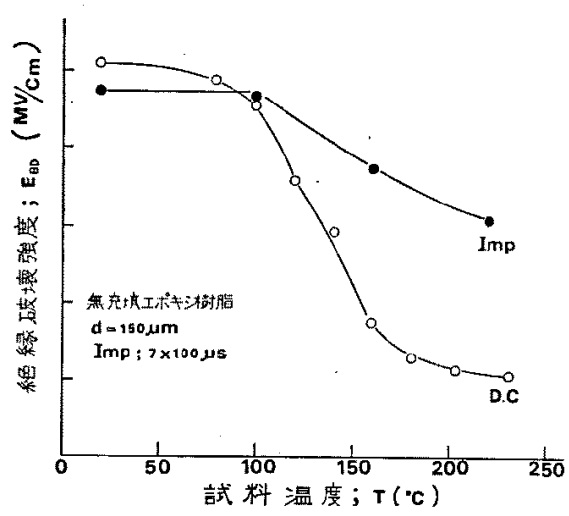

第 12 図 直流および衝撃電压による 絶縁破壊強度の温度依存性

Fig. 12. Temperature dependence of epoxy resin without filler.

(II(dc) 領域)， $\partial E_{B D} / \partial T<0$ (III(dc) 領域)，（前) $\partial E_{E D} /$ $\partial a>0$ となる。（i）の特性を説明する過程としては， 次の三つの過程を挙げるととができる。

(イ) 電子なだれ破壊

（口）材料中に存在する電気的弱点を基点にした破 壊（通常面積効果あるいは体皘効果が考えられ る〉。なお，との場合，電子なだれ破境機構に より最終的に破壊するととす考えられる。

\section{(八)、純熱破濖}

以下，それぞれの可能性について検討する。(イ)の 過程ては，（ii)の実験事実を説明することができず否 定的である。次に，むし(口)の過程で放るとすると， $I(\mathrm{dc})$ 領域化扔いても $\partial E_{E D} / \partial d<0$ になることが期待 されるが，(1)項でも述へたように， $\partial E_{B D} / \partial d \simeq 0$ と 厚さ効果加認奶られないとと加ら否定的である。最後 の(八)の過程上すると、（ii)および( 㧫)の実験事実す 矛盾なく説明することができる。徒って， II $\mathrm{I}_{(\mathrm{dc})}$ およ 


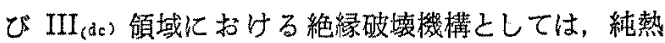
破壊過程が支配的であるものと推測される。

〈5.2〉絶縁破壊強度に及ぼす充てん剂の影響

(1) $I_{(\mathrm{dc})}$ 領域 $\left(20 \sim 100^{\circ} \mathrm{C}\right)$ に扣りる絶縁破填強度

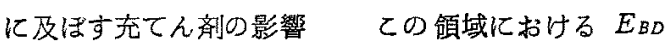
の充てん剂の体積比 $v_{f}$ に対する特性は，

(i) $\partial E_{B D} / \partial v_{f}<0\left(0 \leqq v_{s} \leqq 23.3 \%\right)$

(ii) $\partial E_{B D} / \partial v_{f} \simeq 0\left(23.3 \%<v_{f} \leqq 47.7 \%\right)$

である。栈の增加㲸伴い $E_{B D}$ が低下する原因として は, 電極間に存在する充てん剂粒子(無水アルミナ)界 面での電界の集中効果による可能性が考えられる。そ こで，簡単なモデルとして第 13 困に示すように平等 電界下に 1 個の球形粒子が存在する場合の静電界分布 の計算を試みる(付録参照)。付録で得られる計算結果 より，静電界分布は次式で表わされる。

$$
\left.\left.\begin{array}{rl}
E_{x}= & \left\{\left(\varepsilon_{2}-\varepsilon_{1}\right) /\left(\varepsilon_{2}+2 \varepsilon_{1}\right)\right\}\left(a^{3} / r^{3}\right) \\
& \times\left(3 \cos ^{2} \theta-1\right) E_{0}+E_{0} \\
E_{y}= & \left.(3 / 2)\left\{\left(\varepsilon_{2}-\varepsilon_{1}\right) /\left(\varepsilon_{2}+2 \varepsilon_{1}\right)\right\}\left(a^{3} / r^{3}\right) E_{0} \sin 2 \theta\right)
\end{array}\right\}\right)
$$

最大電界が生じる位置とその大きさを求めるために

$$
\left.f(\theta)=\left|E / E_{0}\right|^{2} \text { (ここで, } E^{2}=E_{x}{ }^{2}+E_{y}{ }^{2}\right)
$$

とおき，これに(1)式を代入して微分すると

$$
(d f / d \theta)=-6 \eta_{2} \sin 2 \theta\left\{(1 / 2) \eta_{2}+1\right\} \ldots \text { (3) }
$$

となる。ここで, $\eta_{2}=\left(\varepsilon_{2}-\varepsilon_{1}\right) /\left(\varepsilon_{2}+2 \varepsilon_{1}\right)$ である。

$(1 / 2) \eta_{2}+1 \neq 0$ より, $(d f(d \theta)=0$ とおいて極值を生 ずる $\theta$ を求めると， $\theta=0, \theta= \pm(\pi / 2)$ を得る。(1)式 より，その祭の極值電界は次の上うに求められる。

(i) $\theta=0$ のとき $(y=0)$

$$
\begin{aligned}
& \left.E_{x}=\left\{2 \eta_{2}\left(a^{3} / x^{3}\right)+1\right\} E_{0}\right\} \\
& E_{y}=0
\end{aligned}
$$

(ii) $\theta= \pm(\pi / 2)$ のとき $(x=0)$

$$
\left.\begin{array}{l}
E_{x}=\left\{1-\eta_{2}\left(a^{3} / x^{3}\right)\right\} E_{0} \\
E_{y}=0
\end{array}\right\}
$$

(4)，(5)式より最大および最小電界は

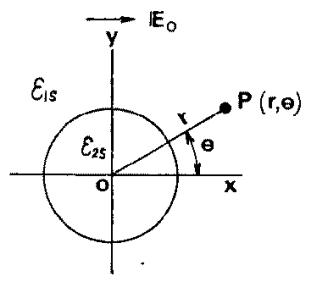

第 13 図 静電界を計算するためのモデル

Fig. 13. Model for calculation of static electric stress.

$$
\left.\begin{array}{ll}
E_{\max }=\left(2 \eta_{2}+1\right) E_{0} & (x=a, y=0) \\
E_{\min }=\left(1-\eta_{2}\right) E_{0} & (x=0, y=a)
\end{array}\right)
$$

と得られる。上式にエポキシ樹脂の比誘電率 $\varepsilon_{1 s}=3.0$, 無水アルミナの比誘電率 $\varepsilon_{2 s}=7.0$ をそれぞれ代入し， この系汸ける電界集中保数 $m^{*}$ を求めると

$$
m^{*}=E_{\max } / E_{0}=1.62
$$

を得る。すなわち，平等電界下に置加九た㼋立充てん 粒子の界面には，最大 $1.62 E_{0}$ の集中電界加形成され る。(4)式で示した $E_{x}$ は距離の 3 乗に比例して減少 するので, $a / x=1 / 2$ の位置では

$$
E=1.62 \times(1 / 2)^{3} E_{0} \simeq 1.08 E_{0}
$$

となり，ほほ平等電界にあどる。この結果より，粒子 間隔 ( 2 個の粒子の中心間の距離) か; $4 a=10 \mu \mathrm{m}$ (無水 アルミナの平均粒子半径は $2.5 \mu \mathrm{m}$ ) 程度離れた粒子系 であれば弧立した粒子として报うことができる。

第 2 表に示したように各充てん部数，体皘比 $v_{f} に$ 対応した平均粒子間隔 $\bar{d}$ (粒子の中心間距離) は 5 部 で $16.2 \mu \mathrm{m}, 40$ 部で $8.4 \mu \mathrm{m}, 100$ 部で $6.5 \mu \mathrm{m}, 200$ 部で $5.6 \mu \mathrm{m}, 250$ 部で $5.3 \mu \mathrm{m}, 300$ 部で $5.2 \mu \mathrm{m}$ で ある。 5 部 $\left(v_{f}=1.5 \%\right)$ 加ら 100 部 $\left(v_{f}=23.3 \%\right)$ の簌囲内での $\bar{d}$ は, 充てん部数の增加䎲伴い減少す る傾向にあるか， 100 部 $\left(v_{f}=23.3 \%\right)$ 加ら 300 部 $\left(v_{f}=47.7 \%\right)$ での $\bar{d}$ は大きく変化しない。

以上のてとより， 5 部 $\left(v_{f}=1.5 \%\right)$ 充てんエポキシ 樹脂の $E_{B D}$ が 0 部の無充てん工六キシ樹脂の $E_{B D}$ K 比べて低下するのは，粒子界面での䉓界が $1.62 E_{0}$ に 增し，界面か電気的破壊の基点として働くためと考え るととができる。また，充てん部数が 5 部 $\left(v_{f}=1.5\right.$ $\%)$ 加 100 部 $\left(v_{f}=23.3 \%\right)$ の範团内での $E_{B D}$ は $v_{f}$ の增加と共低下する。例えば， $20^{\circ} \mathrm{C}$ の場合につい て，無充てんの場合の $\left(E_{B D}\right)_{0}$ 之比較すると

$v_{f}=1.5 \%:\left\{\left(E_{E D}\right)_{1.5} /\left(E_{B D}\right)_{0}\right\} \times 100 \%=71 \%$

$v_{f}=10.8 \%:\left\{\left(E_{B D}\right)_{10.8} /\left(E_{B D}\right)_{0}\right\} \times 100 \%=51 \%$

$v_{f}=23.3 \%:\left\{\left(E_{B D}\right)_{23.3} /\left(E_{B D}\right)_{0}\right\} \times 100 \%=43 \%$

が得られる。この低下は，平均粒子間隔 $\bar{d}$ と密接に 関係しているものと思われる。上述したように，充て ん部数 5 100 部の範囲内で, 平均粒子間瀜 $\bar{d}$ は充 てん部数の增加と共に小さくなる。特に $d<10 \mu \mathrm{m} の$ 場合，第 13 困に示したような平等電界中での弧立し た 1 個の粒子として取り扱うことはできず，近接作用 による新たな影像電荷を考慮する必要がある(7)。この 場合 $m^{*}$ の增加怔考えられ，界面の電界を高め, 従っ て界面での電気的破塄が起こりやすくなるであるう。

一方, 充てん部数 100 部 $\left(v_{s}=23.3 \%\right)$ 以上では 平均粒子間隔 $\bar{d}$ が大体 $5 \sim 6 \mu \mathrm{m}$ 程度よほとんど差が 
なく，従って粒子界面における電界強度があまり增加 せず， $E_{B D}$ む一定になるすのと推測される。

なお，ての領域における充てん部数をパラメータに した $E_{B D}$ の温度依存性 (第 5 图)が，算充てんエポキ シ樹脂の温度低存性亡同一の傾向 $\left(\partial E_{B D} / \partial T \simeq 0\right)$ を持 つととから，絶緑破填機構については〈5・1〉節(1)项 之同様，電子的破壊過程に充てん部数の增加に伴う界 面での電界集中係数の堌大の要素を加えたすの之考え られる。

充てん剂の添加によるエポキシ樹脂の絶縁破壊強度 $\left(E_{B D}\right)$ の低下する原因としては，電界集中効果のほ に充てん剂一樹脂界面の化学的，ならびに物理的不整 (例えば，接着あるいは密着不良，気層の存在など)が 考えられる。長時間寿命特性 ( $V-t$ 特性)およびトリー イング破壊の場合には，無充てん試料に比較して充て ん試料の寿命が長い結果を得ている(8)。乙の場合，卜 リーの枝は充てん昘ー樹脂界面を進展することが明ら かにされており(8), 界面の化学的, 物理的不整が大き な影響を持つものと思われる。

一方，本論文のような比較的短時間破猿試験結果で は，㐬てん試料の $E_{B D}$ のほうが充てん試料の $E_{B D}$ に比較して高い傾向を示している。また絶縁破壊は電 子的過程によるあの之考えられ，との場合，界面にお ける電界集中効果のほうが化学的・物理的不整よりも 大きな要因になるものと考えた。

(2) II (de), III(de) 領域 $\left(100 \sim 220^{\circ} \mathrm{C}\right)$ 亿おける絶縁 破壊強度に及清す充てん剂の影響キシ樹脂の 導電率 $\kappa$ は，ガラス転移点温度 $T$ 。を境に，てれ以上 の高温領域で急激に增加する ${ }^{(9)}$ 。との原因としては, ミクロブラウン運動の活発化に伴う凍結されていた不 純物イオンの解放，あるいはエポキシ自身の熱的解離 飞基つく電荷担体密度の急激な増加が考えられる。

增加したイオンは電気伝導過程のなかで充てん剂粒 子之衙突すると，第 14 四に示すように一部は界面に 沿って伝導キャリアとなり，そして一部は界面の近傍 に沿帯して定常状態に達すると，比較的密度の高い オン性空間電荷を形成するようになるすのと考元られ る。これらの空間電荷は充てん粒子の誘電分極を一層 強める作用と，一方では周りの䉓界を低減する二つの 鹤きがあり，第 14 図に示すような電界分布となる。 結果として，界面における電界集中係数 $m^{*}$ は誘電分 極が強められるため增大するが，一方，界面から少 し離れた部分では逆に電界は低くなる。

ところで，乙の温度領域におけるエポキシ樹脂の絶 䋹破壊機構が純熱破壊過程であるととは，〈5・1〉節 (2) 項で既に述べた。純熱破壊過程における支配的因子の

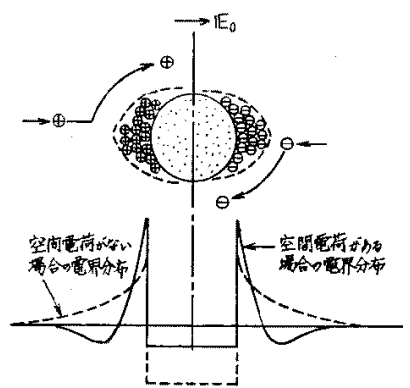

第 14 図 球状粒子近傍の電界分布

Fig. 14. Electric stress distribution near sphere particles.

一つは加熱の項 $\kappa E^{2}$ である。第 14 四に示したよう に，イオン性空間電荷が形成された充てん剂粒子の界 面の近傍では螋界が增大する一方において，キャリア としてのイオンが恬とんど動けないために，加熱の項 $\kappa E^{2}$ 充てん剂粒子の存在しない他のエポキシ樹脂だ けの部分に比べて小さくなるすのと思われる。そのた ぬ，充てん剂粒子近傍の空間電荷が占める空間領域で は純熱破填過程に基づく破填は起こりにくく，破壊は むしろ粒子近傍から離れたエポキシ樹脂単体の部分の みで起こるすのと考えられる。

以上の考察より，III (dc) 領域 $\left(160 \sim 220^{\circ} \mathrm{C}\right)$ における $E_{B D}$ が充てん㓮の体皘比ひノに依存せずほぼ一定とな るのは，絶縁破壊過程がエポキシ樹脂の部分のみで生 し，充てん剂粒子がての過程江寄与しないためである う。100 160 ${ }^{\circ} \mathrm{C}$ までの II(dc) 領域においては, $E_{B D}$ が 0 23.3\%の範囲内で v。の増加と共に徐々に小さ くなる傾向を持つ。これはキャリアとしてのイオン密 度が十分大きくなく，空間笔荷の形成が遅れ，破壊過 程に対する充てん斉の影響が徐々に低減されていくた めと考えられる。

〈5.3〉実験データのばらつきと粒子の分散について

〈4.5〉節で述べたように，実験データのばらつきに ついては，次のようにまとめることができる。

(1) 変動係数と温度の関係では, 室温付近での変 動保数が高温でのそれよりも大きい傾向を示す。

（2）変動係数と充てん鼡の体皘比 $v_{f}$ の関俰で は，5部充てん試料の変動係数が大きい。

5 部充てん試料の $E_{B D}$ のばらつきの大きい原因と しては，電極間の空間に存在する光てん剂粒子の分散 状態のばらつきによるものであるう。試料作成時に 5 部の充てん剂粒子の試料中に均一に分散されるのは， 実際上難しく，粒子の分散にばらつきが生じるものと 考えら机る。第 5 図の結果は，わずか 5 部を充てんし ただけです $E_{B D}$ の低下の著しいことを示している。 
5 部を充てんした場合には，粒子の分散のばらつきに より，試料の場所によっては充てん部数が 5 部以上あ るいは 5 部以下になっているてとが推测され, 従って $E_{B D}$ のばらつきも大きくなるものと考えられる。

\section{6. むすび}

ビスフェノールA形エポキシ樹脂の絶縁破壊機構， 絶縁破壊強度に及ぽす充てん剂粒子の影響拉よび絶縁 破壊機構に及ぼす充てん剂の影響の 3 点につき検討， 考察を行なった。結果を以下㴗約する。

（1）絶縁破㙼機構の検討 室温 $\left(20^{\circ} \mathrm{C}\right) \sim 100^{\circ} \mathrm{C}$ までの温度範国の $I_{(d c)}$ 領域では，定性的には電子的 過程で説明されるが，空間電荷効果などむ考えられ明 確な破㙍機構を断定することは難しい。一方，100〜

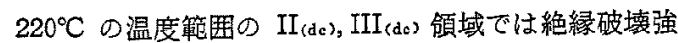
度 $E_{B D}$ の温度依存性, 厚さ依存性, 電圧上昇率侤存 性より，純熱破壊過程により説明される。

（2）絶縁破塄強度に及沽す充てん剂の影響 室温 $\left.\left(20^{\circ} \mathrm{C}\right) \sim 100^{\circ} \mathrm{C} \odot \mathrm{I}_{(\mathrm{dc}}\right)$ 領域に抬いては, 静電 界分布計算より電界集中係数 $m^{*}=1.62$ を得た。すな わち，充てん刘の体皘比 $v_{f}$ か $0 \sim 23.3 \%$ (充てん部 数 100 部) の範囲内では充てん粒子の界面での電界が 增加し， その場合 $v_{f}$ の增加に伴って $m$ * 加增加する ため $E_{B D}$ は低下する。 $v_{f}$ が $23.3 \%$ 贝上では $m^{*} に$ 大きな変化がなく, 従って $E_{B D}$ は $v_{f}$ に依存せず一 定の值となる。160〜220 $\mathrm{C}$ の温度範囲における III (de) 領域では，純熱破罣機構书よびイオン性空間電荷効果 の作用により，見かけ上の充てん剂の効果がほとんど 見られなくなる。なお 100 160年の III(dc)領域は， $I_{(d c)}$ からIII (dc) の状態へ移るための遷移領域であると 解勫される。

（3）絶縁破壊機構に及ぼす充てん剂の影響 すへての領域において本質的な破塄の機構は，充て ん剂粒子が介在してあ变わらないむの之推測される。 (昭和 55 年 4 月 28 日受付, 同 55 年 7 月 28 日再受付)

\section{文献}

(1) 例元ば H. Honjo, et al.: "Short-and Long-Term Strength Characteristics of Particulate-Filled Cast Epoxy Resin", Polymer Engng. Sci., 14, 604 (1974)

(2) R. Lovell: "The Effect of Specimen Size on the Electric Breakdcwn of Unfilled and Filled Epoxy Polymer", IEEE Trans. Elect. Insulation, EI-11, 110 (1976)

（3）奥野·劳賀：実験計面法, p. 82 (昭 45) 培風館

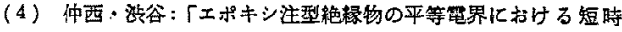

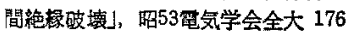

(5) J.J. O'Dwyer: The Theory of Electrical Conduction and Breakdown on Solid Dielectrics, p. 206 (1973) Clarendon Press, Oxford

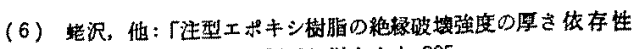

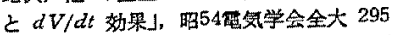

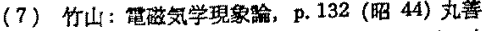

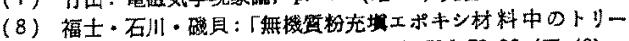

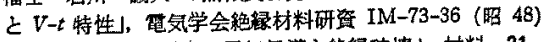

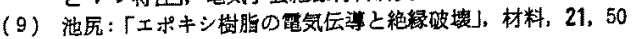
(昭 47)

\section{付 録}

平均電界により分極された誘電体球の内部電界仙場 所によらず一定である。との内部電界を $E_{i n}$ 上する と，極座標で表わした中心 $O$ に対する電位 $V(r, \theta)$ は

(1) $r>a$ (球外)

$V_{e x}(r, \theta)=\left(m / 4 \pi \varepsilon_{1} r^{2}\right) \cos \theta-E_{0} r \cos \theta$

(2) $r<a$ (球内)

$V_{i n}(r, \theta)=-E_{i n} r \cos \theta$

ここで, $\varepsilon_{1}:$ エポキシ樹脂の誘電率， $\varepsilon_{2}$ : 充

てん剂粒子の誘電率， $a:$ 充てん剂粒子の半

径, $E_{0}$ : 印加電界, $m:$ 中心Oに置加九た影

像双極子モーメント

静電界分布に掠いて満足すべき境界条件は

$$
\begin{aligned}
& \left.\frac{1}{r} \frac{\partial V_{i n}}{\partial \theta}\right|_{r=a}=\left.\frac{1}{r} \frac{\partial V_{e x}}{\partial \theta}\right|_{r=a} \\
& \left.\varepsilon_{1} \frac{\partial V_{i n}}{\partial r}\right|_{r=a}=\left.\varepsilon_{2} \frac{\partial V_{e x}}{\partial r}\right|_{r=a}
\end{aligned}
$$

であるから，(付 1)，(付 2 )式をこの二つの条件に代 入して

$$
\begin{aligned}
& E_{i n}=-\left(m / 4 \pi \varepsilon_{1} a^{3}\right)+E_{0} \\
& \varepsilon_{2} E_{i n}=\left(m / 2 \pi a^{3}\right)+\varepsilon_{1} E_{0}
\end{aligned}
$$

この 2 式加ら $m$ について解くと

$$
m=\left\{\left(\varepsilon_{2}+\varepsilon_{1}\right) \varepsilon_{1} /\left(\varepsilon_{2}+2 \varepsilon_{1}\right)\right\} 4 \pi a^{3} E_{0}
$$

（付 7) 式を(付 1 ) 式に代入して

$$
\begin{aligned}
V_{e x}(r, \theta)= & {\left[\left\{\left(\varepsilon_{2}-\varepsilon_{1}\right) /\left(\varepsilon_{2}+2 \varepsilon_{1}\right)\right\}\right.} \\
& \left.\times\left(a^{3} / r^{2}\right)-1\right] r E_{0} \cos \theta
\end{aligned}
$$

従って，極座標の䉓界成分 $E_{r}, E_{\theta}$ は

$$
\left.\begin{array}{l}
E_{r}=-\frac{\partial V_{e x}}{\partial r}=\left(2 \frac{\varepsilon_{2}-\varepsilon_{1}}{\varepsilon_{2}+2 \varepsilon_{1}} \frac{a^{3}}{r^{3}}+1\right) E_{0} \cos \theta \\
E_{\theta}=-\frac{1}{r} \frac{\partial V_{e x}}{\partial r}=\left(\frac{\varepsilon_{2}-\varepsilon_{1}}{\varepsilon_{2}+2 \varepsilon_{1}} \frac{a^{3}}{r^{3}}-1\right) E_{0} \sin \theta
\end{array}\right\}
$$

となり，この式を直交座標成分で表わすと，本文(1) 式の形となる。 